\title{
Health, Physical Activity and the Rio de Janeiro 2016 Olympic Games: Legacy or Fallacy?
}

\author{
Vagner Rosa Bizarro', Tatiane Andreazza Lucchese1, Amanda Maia Breis', \\ Karine Rucker ${ }^{1}$, Minelli Salles Alves Fernandes ${ }^{1}$, Mikele Torino Paletti ${ }^{1}$, \\ Ana Luísa Conceição de Jesus ${ }^{1}$, Raphael Calafange Marques Pereira², \\ Denise Rosso Tenório Wanderley Rocha1, Alberto Krayyem Arbex ${ }^{1,3}$ \\ ${ }^{1}$ Division of Endocrinology, IPEMED Medical School, Rio de Janeiro, Brazil \\ ${ }^{2}$ Division of Rehabilitation Sciences, UNISUAM, Rio de Janeiro, Brazil \\ ${ }^{3}$ Harvard School of Public Health, Harvard University, Boston, USA \\ Email: vavarb@yahoo.com, albertoarbex@gmail.com
}

Received 25 November 2015; accepted 8 January 2016; published 11 January 2016

Copyright (C) 2016 by authors and Scientific Research Publishing Inc.

This work is licensed under the Creative Commons Attribution International License (CC BY). http://creativecommons.org/licenses/by/4.0/

(c) () Open Access

\section{Abstract}

It is generally expected that the Rio de Janeiro 2016 Olympic and Paralympic Games will bring health and social benefits to their host city and to Brazil. This assumption comes from "common sense", as a logical conclusion arising from the fact that host cities "inspire" and stimulate lifestyle changes. Benefits are also expected on tourism, self-image, architecture and the economy of the country as a whole. But are these expectations real and evidence-based? What parts of these "facts" are concrete and which ones are not? This paper suggests available ways of quantifying positive effects of hosting an Olympic Game, and puts the focus of this approach on the Rio de Janeiro 2016 Olympic Games and their true legacy, seeking scientific certainties.

\section{Keywords}

Physical Activity, Olympic Games, Paralympic Games, Olympic Legacy, Rio de Janeiro, Rio 2016

\section{Introduction}

Rio de Janeiro is a "sports city". This assumption arises immediately when we think of the warm weather, large beach areas and the idea of "eternal summer" that is associated with this city. Besides, it hosted many megaevents happened within a decade: the Panamerican Games (2007), the FIFA World Soccer Games (2014) and 
the Olympic Games (2016), the latter to be hosted in Rio de Janeiro during August and September 2016. But scientific studies do not confirm this stereotype of a "sports city". Surveys held in Brazil and specifically in Rio de Janeiro showed that more than $75 \%$ of the population of Rio "never or almost never" perform any physical activity at least 30 minutes, one day a week. Only $13 \%$ of the Brazilian population is considered "physically active" [1] [2].

Would it be possible to change this difficult scenario? May we start this change with the Olympic and Paralympic Games in 2016? These are some of the questions this article intends to answer.

\section{Rio 2016: Health Legacy}

The idea that such a big event as the Olympic Games could bring enormous benefits for the population's health and well-being has been used, by most of previous hosts, as one of the main arguments for receiving the Games. The huge amount of money necessary to prepare a city for the Olympics becomes more acceptable when those costs intend-at least theoretically — to improve several dimensions of a city, such as infrastructure, tourism, jobs and health promotion — the latter being possible through direct and indirect investments [3].

Since the 2012 London games [4] and continuing to 2016 Rio de Janeiro games [5] the olympic projects addressed specifically the Olympic legacy on health promotion [6]. The legacy would be the socioeconomic related determinants [6]. The health legacy was also analyzed by editors of leading scientific journals, including The Lancet and the British Medical Journal [5] [7].

A review study that has served as a reference to relate the impact of sporting events in the lives of populations was developed by UK Sport (2011). This study evaluated if the participation as spectator in three major sports events in England in the summer of 2010- "Women's Hockey Champions Trophy in Nottingham”, "Triathlon World Championships Series" in Hyde Park, London, and "IRB Women's Rugby World Cup in Guildford and Twickenham", could influence stimulating physical activity. The authors concluded that mega events may inspire people, but it neither proved that this inspiration turns into real life changing and "inspires" the beginning of a physical activity, nor even encouraged people to keep up with it. A possible explanation is that behavior changes involve a multifactorial chain: they are usually not linked to one single reason [8].

The same conclusions are summarized at an exemplary systematic review of evidence based data regarding the London 2012 Olympic and Paralympic games [9]. Although there are a number of papers that discuss positive and negative legacies of mega sports events in the economic and social context, there are few studies about legacy in sports, and more specifically in physical and sports activity levels in the general population [4]-[7] [10]. The impact assessment in sports is highly difficult. Many variables may interfere with the interest of the population in these activities. Thus, it is hard to attribute a cause-effect relationship between the implementation of a particular event and the sport and physical activity levels of the population [7] [10] [11]. Another barrier for studies in the area is that as there is wide variation in research protocols that raise physical activity levels of populations, it is difficult to compare the levels pre and post events. The few published studies on this subject may be questioned due to methodological and/or ideological issues. In other words, doubts remain about the validity of some studies, not only because of the above mentioned reasons, but simply because some of them were supported by stakeholders from both government and institutions that disclose clear interests in finding positive associations [12].

A clear benefit to Brazilians would be to increase in physical activity levels, both in local, regional and national levels. This kind of legacy could be assessed using VIGITEL [11], a surveillance system of risk and protective factors for chronic non communicable diseases (NCDs). Using a simple telephone survey, this system could generate series of data measured before and after the games, but this has not been suggested so far. The Rio 2016 Olympic Games can be analyzed as a complex intervention in health, which makes the assessment of his legacy a multifaceted action [13], although some general issues are critical [7]: a) developing cost-effectiveness studies that measure outcomes of public interest and collective health; b) seeking additional effects and assigning the actions and interventions linked to the Olympic Dossier. These results should be compared to a "control" scenario model, i.e., what would have happened if the Olympics had not been held at Rio. These are thrilling prospects for short term researches on the field, regarding the fact that the Olympic Games in Rio de Janeiro have still did not take place. There is time to plan and to act [14].

\section{Health, Physical Activity and the Olympic Games}

Sports and healthy living represent an investment in the long-term health of the nation. Efforts have been made 
to ensure a legacy which reaches beyond sport, to help to drive change in the nation's health and the way people live [15].

The concept of a health legacy of the Olympic Games was defined as: "The sustainable, positive health impacts on the host city or country, associated with the hosting of the Olympic Games”, formally discussed at a symposium in Lausanne in 2002 entitled "The legacy of the Olympic Games 1984-2000" [16].

In recent years, the IOC Medical Commission has reoriented its work from a major focus on anti-doping issues, which recently have largely been taken over by the World Antidoping Agency, to focusing more on the health protection of current and future athletes and the health of the host city population [16].

The health legacy is multifaceted, with many potential long term impacts. These fall broadly into the following categories: improved capacity in traditional medical services required for hosting the Olympics; a strengthened public health system, including disease surveillance, risk management and health emergency response; an enhanced living environment for the host city citizens; and increased health awareness among athletes, visitors, and host country residents through successful health education and campaigns prior to and during the Olympic Games [16].

As previous cities hosting the Olympic Games, Beijing was also successful in providing high quality medical services. These included "athlete-friendly" health care in the polyclinics and venues, an intricate hospital network and reliable pre-hospital emergency health services, strengthened anti-doping systems in an attempt to assure a drug-free Games, and a new research project on sports injury prevention and treatment. These and many other initiatives have not only left the host city with improved health infrastructures and advanced technologies, but also an impressive resource of trained health professionals of great benefit to the host city long after the ending of the Games [16].

Another example of health impact is a research conducted on four categories of impact, largely based on a literature review and a on series of consultations and workshops with key stakeholders, especially within London: First, socio-economic health impact, which takes into account how potential socio-economic developments affect public health through their effects, for example, on levels of income and job security, on social cohesion and on access to housing and education. Second, physical health impact which traces the effects of changes in the quality of the physical environment, the amenity and the transport system. Third, mental health impact which reflects individuals' ability to balance all aspects of life arising from their social, economic, physical and emotional interactions by managing their surroundings and making choices throughout their lives. Fourth, the well-being health impact which reflects the extent to which individuals (expect to) feel contented (for examples, happy, healthy and prosperous): a negative impact can be reflected in depression, anxiety and stress [17].

\section{Sports Legacy}

\subsection{Olympic Games}

Among the welfares promoted by the Games' hosts, many of them focus on those that are sports-related. Some can be highlighted, such as increased sport participation, the creation of new sports programs and the improvement of sport infrastructure, as well as the formation of sport-related social capital intended to revitalize communities. These benefits are directed not only to the host city, but to all of the host nation [18].

The "Olympics Training Center" will emerge from the other six venues. Its goal will be to provide high-level facilities for several sports. It will also be available for those Olympic Experimental School's students as well as for other social projects [19]. As appealing as this idea of improvement may seem, however, it is not so easily achieved. So far, many were the host cities that believed in such development but were not able to prove it a reality. Studies have not revealed yet, for instance, enough evidence of improvements in health in the city of London after the Games in 2012, nor an increased participation in physical or sporting activities for host countries. The same occurs to other health benefits [7].

The Olympic Games are a major milestone in the host cities, creating an impact that has grown since the 1984 Olympics, when the Games have become larger and more expressive, involving more athletes, modalities and media [20].

The importance of sport to society can be demonstrated in several ways. In fact, the sport has a significant impact mainly in education and health of the population and may contribute to overcoming social problems experienced by the country. Moreover, it is an activity that is gaining economic importance, given the volume of funds and the growing number of companies involved. The actions for development of this activity in the coun- 
try need to be comprehensive covering since the formation of athletes and construction of sports venues to create professional leagues and changes [12].

Thus, the Olympic Games, has great influence on the practice of physical activities in the countries that host the games. There is no denying the importance and value of sport among people, especially young people. With the Olympics, young people are attracted and stimulated by the practice of sport, with the spirit of competition, the cult of exuberance and physical perfection, as did the Greeks, nowadays so evident [12].

\subsection{Paralympic Games}

The Paralympic Games have evolved from a cultural to a true sports event, and its importance grew during the last editions. The empowerment of disabled athletes is a key goal of these games, and many studies seek to better understand how these Games arouse an increased concern from the general public, since they represent the human capability to overcome, the resiliency and the high development of rehabilitation processes. There are broad sociological questions involved with physical impairment and performance, but the Paralympic Games are clearly in a rise, and surely represent a positive movement towards a better understanding, social and sports inclusion of athletes with physical disabilities [21].

In Rio de Janeiro, there are some laboratories working specifically on paralympic performance at the Unisuam's post graduation in Rehabilitation Sciences, such as the "Lab of Human Movement Analysis" and the "Neurofunctional Performance Lab". They study the special conditions under which top para-athletes perform, in order to build scientific knowledge in this field. These research lines are highly important for Brazil, and may pose an important sports legacy for the host country, especially because Brazil traditionally performs significantly better in Paralympic Games (ranked $9^{\text {th }}$ at the Beijing 2008 Paralympic Games and $7^{\text {th }}$ at London Paralympics) than in Olympic Games (ranked $23^{\text {th }}$ at the Beijing 2008 Olympic Games and $22^{\text {th }}$ at London Olympics) [22].

The greatest legacy of the Paralympic competition is not simply to win a medal or the competition itself, but mainly the example these athletes give to hundreds of thousands of people who live stigmatized by physical and mental disabilities. Even those who do not wish to be athletes, the average citizen can find inspiration, building a parallel of their lives with those who overcome several difficulties with lots of courage, persistence and dedication towards sports. It is relevant to know that there are people who, despite difficulties of all kinds, are able the fight and win in sports. This is an attitude that shoes optimism, raises self-esteem and reorient sperspectives for many people, besides acquiring an attitude of acceptance and respect for individual differences [23].

It seems to be indeed a challenge posed by the issue of integration of disabled athletes into a high performance level sports competition. The goal to overcome difficulties through sports is clearly within the message of Olympism. Therefore, the Paralympic Games are a key part of the Rio 2016 Olympic Games, and bring along a remarkable legacy in society and culture [16].

\section{Social Legacy}

Last July 2015, the Rio de Janeiro city government disclosed the legacy the 2016 Olympic Games intends to leave to the city. From the start it was advertised that one of the main goals of hosting the Games was to leave a legacy for the city, with great improvements in social and economic spheres. The Games would not be their only concern, but instead, the future that would arise and become possible to build through and after the event itself [19].

The two main venue clusters will be transformed into different facilities for education, social projects, public leisure and elite-level sports. Most of the venues will remain untouched, whilst two of them, thanks to the "nomadic architecture", will become part of several new projects, such as schools and aquatics centers. Amongst those remaining untouched, some will become an Olympic Experimental School, with space for 850 full-time students. These institutions shall combine academic teaching with top-level sports training [19].

Inadequate attention to planning the post-Games period and the legacy of the Olympic Games is a risk [24]. The host cities usually focus on preparing to win the right to host the Games, planning grand and successful Olympics, but the post-Games period is neglected, because of lack of economic interest. It is important to plan what will be done with the huge infrastructure assembled for and by the Games [20].

Toronto and Vancouver, both in Canada, are also good examples of how the Olympic Games could bring positive consequences to the host cities. Their populations emphasized the idea of the need of public benefits to be 
brought by the games. A study held after the Vancouver Winter Games showed that hosting the game contributed to improve the image of Canada as a destination for Americans, besides increasing the feeling of pride of their own country among Canadian [25].

The legacy of investment in security infrastructure, urban revitalization, public transport, telecommunications, energy and data transmission is perhaps the greatest benefit that could happen to emerging economies like Brazil and the city of Rio de Janeiro, where huge architectural projects as the New Harbour in downtown ("Porto Maravilha") and the expansion of the subway to the western region of the city would otherwise not become viable in a short term [26].

Some authors also refer to a neoliberal influence of the organization of the games over the host country, because the dynamics of such mega-events necessarily include thorough negotiations with multinationals and the dominant economic system after all, what could be positive for the nation's growth [27].

All these achievements will also allow the city of Rio to host major international sports events, concerts and exhibitions, in a phenomenon called a "festivalisation" of the city, an inclusion of some parts of the "Global South" (Steinbrink). These are some of the heralded future benefits advertised by the Games organizers [28].

In the social sphere, the sport has pedagogical function in the individual formation process, stressing discipline, respect for hierarchy and the "rules of the game", solidarity, team spirit and other factors of human development. Can be used as social rescue tool (Italy, for example, organized a program for recovering addicts through sports) and has also been considered an antidote to violence (in New York, the Midnight leagues contributed to the decrease in crime rate). In the economic sphere, the sport involves a lot of financial resources; moves a large and diversified manufacturer specializing in the production of sports equipment, uniforms, protective equipment and footwear, among others.

The growth of the Second Time Program (STP), a program supported by the United Nations, which provides access to sports in public schools, including currently one million children. Between 2009 to 2016, the STP intends to grow to cover 3 million children [7]. In addition, the School and University Games, an initiative awarded by the International Olympic Committee (IOC), will be expanded. Of the current 2.5 million young people, the event will meet 5 million students, which will encourage the participation in Olympic sports [10].

The social importance of the Olympic Games can be assessed by parallel initiatives, such as the first World Indigenous Games, held at Palmas, Brazil, during October 2015. This innovative event counted with 21 countries, and its main goals were to empower these communities worldwide and to affirm the self-determination of indigenous people [29].

\section{Olympic Games: Early and Future Examples}

Hosting a mega event like the Olympics involves economic, social and environmental considerations [5]. According to Cashman [20], there are several types of impact to be expected: changes in the design of cities, changes in the physical structure and environment, representing the culture of a city and country, improvements in transportation, rising costs and taxes, potential increase in tourism and business, creation of new sites that can be used by the community after the Games, and community involvement as volunteers [20].

In this context, it becomes extremely important to study the established strategies and the possible impact before, during and after the Games because often the legacy turns into a huge public debt instead of concrete results, as the example of the 2007 Pan American Games (PAN 2007) showed [30].

About the prospects for the Olympic Games in Rio de Janeiro of 2016, a most expected legacy refers to the transport infrastructure, which aims to: improve public transport, especially high capacity, opening of new road connections in the north-south direction, increasing capacity to meet demand shifts in the east-west direction [31].

Since the nominations to previous Olympic Games and the organization of the PAN 2007, the mega sporting events has been one of local government's strategies to strengthen economic vocations of the city as the service sector, including tourism, economy linked to sport the cultural sector. Rio de Janeiro shares those similar goals with other host cities [12].

A Olympic Legacy Committee of Rio 2016 - an alliance made up of government, by companies, by the Brazilian Olympic Committee and groups and community-organizations was created to oversee all projects associated with the Olympic legacy from 2009 to 2020 [9]. 


\section{History}

According to existing historic manuscripts, the first ancient Olympic Games were celebrated in 776 BC in Olympia [32].

From ancient times to the modern day and age, mankind has progressed scientifically, technologically and socially, eliminating the horrors of that time, aimed at the sport with its true value [32]. The first edition of the modern Olympic Summer Games was held in 1896 in Athens (Greece), and the first Olympic Winter Games in 1924 in Chamonix (France) [33].

It was Pierre de Coubertin who dreamt up this ambitious project. Drawing inspiration from the ancient Olympic Games, he founded the International Olympic Committee (IOC) in 1894 in Paris, with the goal of organizing the first Olympic Games of modern times [33]. Coubertin devoted his life to the reform of education and youth in France. Fascinated by the English education system, which included sport in the teaching program (a new idea at the time), he sought to convince his contemporaries in France that sport could be beneficial for young people. Coubertin brought a modern and international dimension and succeeded in re-establishing the Games. But for him, the Games were not an end in themselves. Rather they were part of a much broader project: education through sport [21].

\section{Olympic Values}

Olympism is a philosophy of life, exalting and combining in a balanced whole the qualities of body, will and mind. Blending sport with culture and education, Olympism seeks to create a way of life based on the joy of effort, the educational value of good example, social responsibility and respect for universal fundamental ethical principles [3].

The philosophy of Olympism is an essential element of the Olympic Movement and the celebration of the games. It is also what makes them unique. The pursuit of this ideal and the other "fundamental principles of Olympism" gives rise to a series of values, which are applicable both on the field of play and in everyday life [21].

The IOC has identified the following three Olympic values [21] [34]:

- Excellence. In the Olympic ideal, this value refers to giving one's best, on the field of play or in life, without measuring oneself with others, but above all aiming at reaching one's personal objectives with determination in the effort. It is not only about winning, but mainly about participating, making progress against personal goals, striving to be and to do our best in our daily lives and benefiting from the combination of a strong body, will and mind.

- Friendship. Men and women are at the Centre of the Olympic Movement's focus encouraging the links and mutual understanding between people. This value broadly refers to building a peaceful and better world through solidarity, team spirit, joy and optimism in sport. The Olympic Games inspire humanity to overcome political, economic, gender, racial or religious differences and forge friendships in spite of those differences. The athletes express this value by forming life-long bonds with their team-mates, as well as their opponents.

- Respect. In the Olympic ideal, this value represents the ethical principle that should inspire all who participate in the Olympic programs. It includes respect for oneself and one's body, respect for one another, for rules and for the environment. It thus refers to the fair play that each athlete has to display in sport, as well as avoiding doping [21] [34].

These three core values are conveyed through the Olympic symbols. The motto embodies excellence by encouraging athletes to strive to do their best. The flame symbolizes friendship between peoples with the torch relay usually travelling through different countries in the world. The rings represent respect, bringing all nations and all five continents together without discrimination. The principles shown are universality and humanism [35].

A very powerful symbol, the five rings are the visual representation of Olympism. It was Pierre de Coubertin himself who designed the symbol. The five rings represent the five continents. They are interlinked to show the universality of Olympism and how athletes from all over the world come together for the Olympic Games. On the Olympic flag, the rings appear against a white background. Combined in this way, the six colors of the flag (blue, yellow, black, green, red and white) represent all the nations. It is therefore not the case that each of the colors is associated with a particular continent. Today, the symbol is one of the most widely recognized in the world. Its use is subject to very strict rules enacted by the IOC. It is important to note that there is just one 
Olympic symbol. For the other identifying elements described below, other terms are needed [21] [35].

A motto is a phrase which sums up a life philosophy or a code of conduct to follow. The Olympic motto is made up of three Latin words: faster, Higher and Stronger. These three words encourage the athlete to give his or her best during competition. To better understand the motto, we can compare it with the Olympic creed: The most important thing in life is not the triumph, but the fight; the essential thing is not to have won, but to have fought well. Together, the Olympic motto and the creed represent an ideal that Coubertin believed in and promoted as an important life lesson that could be gained from participation in sport and the Olympic Games: that giving one's best and striving for personal excellence was a worthwhile goal. It is a lesson that can still be applied equally today, not just to athletes but to each one of us [21] [35].

These symbols are much more than emblems and people should immediately be able to associate them with fundamental values for sport and life in general [35].

\section{Conclusions}

The projects, goals and expectations for the Rio 2016 Olympic Games must be sustainable and inclusive. Otherwise, those who don't have a powerful voice in society will remain unheard and excluded from the wide improvements likely to be brought by the Games. Yet these legacies will not emerge individually simply by "the power of sport"; they need to be grounded in extensive planning and political processes meant to keep on going even after the 2016 Olympic Games are over.

One of the scopes of the Olympic ambitions of the Brazilian government, in fact, is the massification of sports in the school environment. Hosting mega sporting events may bring opportunities, and strengthen actions to encourage the population's physical activities of leisure and health promotion. These are very important in an increasing context of chronic degenerative diseases associated with a sedentary lifestyle and habits of unhealthy life, which is the case. For this purpose, governments and institutions linked to sports should use media coverage intended for mega sports events to help boost the development of the sport and the dissemination of physical activity in the country. But this is not so easily achieved-recent examples are frustrating ones.

Ribeiro stated that "the ideal legacy is what can be positive in all aspects: sport, economic, social and environmental". And that is the main challenge for a country that chooses to host a mega event such as the Olympic Games: to transform the entire investment in real growth for the host city and host country [12].

A desired legacy can only be achieved if it is based on extensive planning and if it focuses on some main points. It must be connected with existing social structures and the everyday lives of local populations.

In conclusion, a true legacy in health, as consequence of hosting the Olympic Games, should not be taken for granted. It is essential to evaluate these facts through studies with high methodological quality, based on projects developed before, during and after the event. There is a window of opportunity for many to grow and evolve, but the Games are not and should not be regarded as a solution for structural problems.

\section{Acknowledgements}

We would like to thank Prof. Dr. Jörg Königstorfer, Head of the Chair of Sports and Management at the Teschnische Universität Munich, Germany, for inspiring the idea of this paper, and for future research prospects. We also thank Raphael Calafange, from UNISUAM Brazil, for specific technical considerations regarding the Paralympic Games. Finally, we thank Professor Dr. Aline Marcadenti and Prof. Dr. Lamartine DaCosta for their lifetime examples of dedication to interdisciplinary science.

\section{References}

[1] Monteiro, C.A., Conde, W.L. and Matsudo, V.R. (2003) A Descriptive Epidemiology of Leisure-Time Physical Activity in Brasil, 1996-1997. Revista Panamericana de Salud Pública/Pan American Journal of Public Health, 14, $246-254$. http://dx.doi.org/10.1590/S1020-49892003000900005

[2] Dumith, S.C. (2009) Physical Activity in Brazil: A Systematic Review. Cadernos de Saúde Pública, Rio de Janeiro, 25, S415-S426. http://dx.doi.org/10.1590/s0102-311x2009001500007

[3] Demarzo, M.M.P., Mahtani, K.R., Slight, S.P., Barton, C. and Blakeman, T. (2014) The Olympic Legacy for Brazil: Is It a Public Health Issue? Cadernos de Saúde Pública, 30, 8-10.

[4] Mahtani, K.R., Protheroe, J., Slight, S.P., Demarzo, M.M.P., Blakeman, T., Barton, C.A., Brijnath, B., et al. (2013) Can the London 2012 Olympics "Inspire a Generation” to Do More Physical or Sporting Activities? An Overview of 
Systematic Reviews. BMJ Open [Internet]. http://bmjopen.bmj.com/content/3/1/e002058.full.pdf+html

[5] Weed, M. (2010) How Will We Know If the London 2012 Olympics and Paraolympics Benefit Health? BMJ, 340, c2202. http://dx.doi.org/10.1136/bmj.c2202

[6] Dossiê de Candidatura do Rio de Janeiro a sede dos jogos olímpicos e Paraolímpicos [Candidature Dossierfrom Rio de Janeiro to host the Olympic andParalympic games], 2016, V.1.

[7] Welling, K., Datta, J., Wilkinson, P. and Petticrew, M. (2011) The 2012 Olympics Assensing the Public Health Effect. Lancet, 378, 1193-1195. http://dx.doi.org/10.1016/S0140-6736(11)60550-3

[8] International Olympic Committee (IOC), Implementing the Olympic Movement's Agenda 21. Sustainability through Sport. 2012.

http://www.olympic.org/Documents/Commissions PDFfiles/SportAndEnvironment/Sustainability Through Sport.pdf

[9] D Louise Mansfield, L., Wellard, I., Chatziefstathiou, D. and Dowse, S. (2009) A Systematic Review of the Evidence Base for Developing a Physical Activity and Health Legacy from the London 2012 Olympic and Paralympic Games. Department of Health, Canterbury Christ Church University, Kent.

[10] Department of Education Rio de Janeiro city. Programa de Alimentação escolar [Schoolfeedingprogram]. 2014. www.ebc.com/noticias/2015/05/olimpiadas-vao-deixar-legado-da-alimentacao-saudavel-nas-escolas-publicas-do-rio

[11] Malta, D.C., Moura, E.C., Castro, A.M., Cruz, D.K.A., Monteiro, Neto, O.L. and Monteiro, C.A. (2009) Padrão da atividade física em adultos brasileiros: Resultado de um inquérito por entrevistas telefônicas 2006 [Pattern of Physical Activity in Brazilian Adults: Results of a Survey by Telephone Interviews in 2006]. Epidemiologia e serviços de saúde, 18, 7-16.

[12] Souza, D.L. and Saks, P. (2013) Legados esportivos de megaeventos esportivos: Uma revisão da literatura (Sporting Legacy of Mega Sports Events: A Literature Review). Motrivivência, 41, 42-46. http://dx.doi.org/10.1136/bmj.a1655

[13] Craig, P., Dieppe, P., Mancintyre, S., Michie, S., Nazareth, I. and Petticrew, M. (2008) Developing and Evaluating Complex Interventions: The New Medical Research Council Guidance. BMJ, 337, a1655.

[14] Sampson, A., Harden, A., Tobi, P. and Renton, A. (2012) Promoting a Healthy Legacy for the Olympic Park: Findings from a Pre-Games Study. Perspectives in Public Health, 132, 64-65. http://dx.doi.org/10.1177/1757913912437675

[15] Mayor of London (2013) Inspired by 2012: The Legacy from the London 2012 Olympic and Paralympic Games. https://www.gov.uk/government/uploads/system/uploads/attachment_data/file/224148/2901179_OlympicLegacy_acc.p df

[16] Dapeng, J., Ljungqvist, A. and Troedsson, H. (2008) The Health Legacy of the 2008 Beijing Olympic Games: Successes and Recommendations. World Health Association. http://www.olympic.org/Documents/Commissions_PDFfiles/Medical_commission/The_Health_Legacy_of_the_2008 Beijing_Olympic_Games.pdf

[17] Department of Culture, Media and Sport of London (2005) Olympic Games Impact Study: Final Report. http://www.gamesmonitor.org.uk/files/PWC\%200lympicGamesImpactStudy.pdf

[18] Coakley, J. and Souza, D.L. (2013) Sport Mega-Events: Can Legacies and Development Be Equitable and Sustainable? Motriz: Revista de Educação Física, 19, 580-589. http://dx.doi.org/10.1590/s1980-65742013000300008

[19] Comitê Olímpico Brasileiro (2015) Rio 2016 Olympic and Paralympic Games Venues to Leave Sporting, Educational and Social Legacy to City. Comitê Olímpico Brasileiro, Brazil. http://www.rio2016.com/en/news/rio-2016-olympic-and-paralympic-games-venues-to-leave-sporting-educational-andsocial-legacy-to

[20] Cashman, R. (2002) Impact of the Games on Olympic Host Cities: University Lecture on the Olympics. Centre d’Estudis Olímpics (CEO-UAB). International Chair in Olympism (IOC-UAB), Barcelona.

[21] International Olympic Committee (IOC) (2013) The Olympic Museum, Lausanne 3rd Edition. Olympism and the Olympic Movement. http://www.olympic.org/documents/reports/en/en_report_670.pdf

[22] International Paralympic Movement (2015) www.paralympic.org

[23] Brazilian Paralympic Committee (2015) www.cpb.org.br

[24] Ribeiro, C.H.V., Soares, A.J.G. and Da Costa, L.P. (2014) Percepção sobre o legado dos megaeventos esportivos no brasil: O caso da copa do mundo FIFA 2014 e os jogos olímpicos Rio 2016. Revista Brasileira de Ciências do Esporte, 36, 447-466. http://dx.doi.org/10.1590/S0101-32892014000200012

[25] Armenakyan, A. and Helsop, J.N. (2010) Does Hosting the Olympic Games Matter? Canada and Olympic Games Images before and after the 2010 Olympic Games. International Journal of Sport Management and Marketing, 12, 111-140.

[26] Fonseca, M.L.M. (2011) Externalidades e Bens Públicos em Grandes Eventos Esportivos: Avaliações e Perspectivas 
(Externalities and Public Goods in Major Sporting Events: Reviews and Perspectives). In: Planejamento, Patrimômino Cultural e Eventos Esportivos: Construindo Estratégias.

[27] Gaffney, C. (2010) Mega Events and Socio-Spatial Dynamics in Rio de Janeiro. Journal of Latin American Geography, 9, 7-29.

[28] Steinbrink, M. (2013) FestiFAVELisation: Mega-Events, Slums and Strategic City-Staging-The Example of Rio de Janeiro. Journal of the Geographical Society of Berlin, 144, 129-145.

[29] Indigenous World Games (2015). http://en.jogosmundiaisindigenas.com/

[30] Pires, S.P., Baptista, L.F.S. and Portugal, L.S. (2013) Megaeventos e o Desenvolvimento Urbano e Regional: Uma Análise das Especificidades e Impactos Provenientes dos Jogos Olímpicos e Um Panorama Para a Cidade do Rio de Janeiro (Mega-Events and the Urban and Regional Development: A Review of the Specificities and Coming Impact of the Olympic Games and an Overview for the City of Rio de Janeiro). Encontros Nacionais de ANPUR, Anais.

[31] Special Committee for Urban Legacy of Department of Urbanism of Rio de Janeiro City (2009) Plano de Legado Urbano e Ambiental: Olimpíadas Rio 2016 (Plan of Urban and Environmental Legacy: Olympics 2016). Secretaria Municipal de Urbanismo-Prefeitura da cidade do Rio de Janeiro.

[32] International Olympic Committee (IOC) (2012) The Olympic Games of Antiquity. http://www.olympic.org/documents/reference_documents_factsheets/the_olympic_games_of_game_antiquity.pdf

[33] International Olympic Committee (IOC) (2013) The Olympic Museum, Lausanne 3rd Edition. The Modern Olympic Games. http://www.olympic.org/Documents/Reports/EN/en_report_668.pdf

[34] Brazilian Olympic Committee (2014) Olimpismo. Movimento Olímpico. http://www.rio2016.com/educacao/sites/default/files/midiateca/aulas/movolimpico_aula1.pdf

[35] International Olympic Committee (IOC) (2007) The Olympic Symbols. 2nd Edition. http://www.olympic.org/documents/reports/en/en_report_1303.pdf 